\title{
EVALUATING PRODUCT PLANS USING REAL OPTIONS
}

\section{Prasenjit Shil}

\author{
Engineering Management and Systems Engineering Department, \\ University of Missouri Rolla, Rolla, Missouri, USA
}

\section{Dr. Venkat Allada}

Professor, Engineering Management \& Systems Engineering Department, 119 Fulton Hall, University of Missouri-Rolla, Rolla, Missouri, USA

Product planning helps a company to strategically plan its current and future product platforms and offer product variants in the marketplace. Product platforming is widely touted as a successful strategy for mass customization. However, due diligence should be exercised before implementing any product platform strategy. The product planning exercise should account for future uncertainties. Traditional financial tools such as the net present value (NPV) are static since they do not compensate for any exogenous and endogenous uncertainties during the course of the project. The crux of the problem lies in the evaluation model that is used for evaluating the product planning projects. While many view uncertainties in a product planning project as problematic, it can also be viewed as a source of new opportunities. We argue that uncertainties should be an integral part of the evaluation model. If the future possibilities (or strategic options) are not considered in the evaluation model, a corporation may face a "myopic syndrome."

In this article, we consider two important product planning decisionsplatform decisions and product variant decisions. The platform decision involves strategic selection of a concept product platform from various possible alternative concept product platforms. The product variant decision involves deciding how long a company should continue to offer its current product variant in the marketplace and whether the existing product

Address correspondence to Dr. Venkat Allada, Professor, Engineering Management \& Systems Engineering Dept., 119, Fulton Hall, University of Missouri-Rolla, Rolla, MO 65409. E-mail: allada@umr.edu 
variant should be discontinued, scaled down, or scaled up with additional product features. To address the two aforementioned decisions, we developed a real options-based methodology that considers technical, project implementation, and market-related uncertainties. The proposed methodology uses a binomial and quadranomial lattice approach to build a decision tree. Product planning decisions at various decision tree nodes are evaluated using a risk-neutral option valuation methodology. We demonstrate the working of the proposed methodology using an illustrative example.

\section{INTRODUCTION}

An effective product planning strategy is critical for the success of any firm. Product planning is defined as a process that envisions which product variants should be introduced and when they should be introduced in the market (Ulrich and Eppinger, 2000). Increasing competition and dynamic consumer needs are forcing firms to shrink the product life cycle and expedite the introduction of new products (Pine, 1993; Ulrich, 1995; Fang et al., 2002; Pavlic, Pavkovic, and Storga, 2002). One way to keep up with the rapid pace of product introductions is to deploy platform-based product family techniques (Meyer and Lehnerd, 1997). Examples of product platforming exist among popular consumer products such as Sony Walkman (Uzumeri and Sanderson, 1995; Sanderson and Uzumeri, 1995); HP printers (Meyer and Lehnerd, 1997); Audi, Volkswagen, Seal, and Skoda (Pavlic et al., 2002); and Lexmark (Coleman, 2003). A product platform is a set of common assets that are used to create a large number of product variants or derivative products (Meyer and Lehnerd, 1997; Tichem, Andreasen, and Riitahuhta, 1999). Typically, the investment in a platform development project is almost 2-10 times more than the cost to develop a derivative product (Ulrich and Eppinger, 2000). Therefore, it is very crucial for companies to make the right product platform decisions.

Meyer and Lehnerd (1997) described the case of HP product roadmap, as shown in Figure 1. We present the highlights of their description of the HP case since it served as our motivation to undertake the proposed solution methodology described in this article. Figure 1 shows that HP started parallel development of Platform "600" and Platform "800" while refining the existing Platform "500." Platform "500" was updated several times with new features and technology to meet the customer demands. The cartridges and color balancing and the mixing technology used in Platform "500" could not fully satisfy the customer needs. Hence, HP initiated the development of a completely new platform. Though many subsystems from the original Platform "500" were carried over to the new Platform "600," it required enormous 


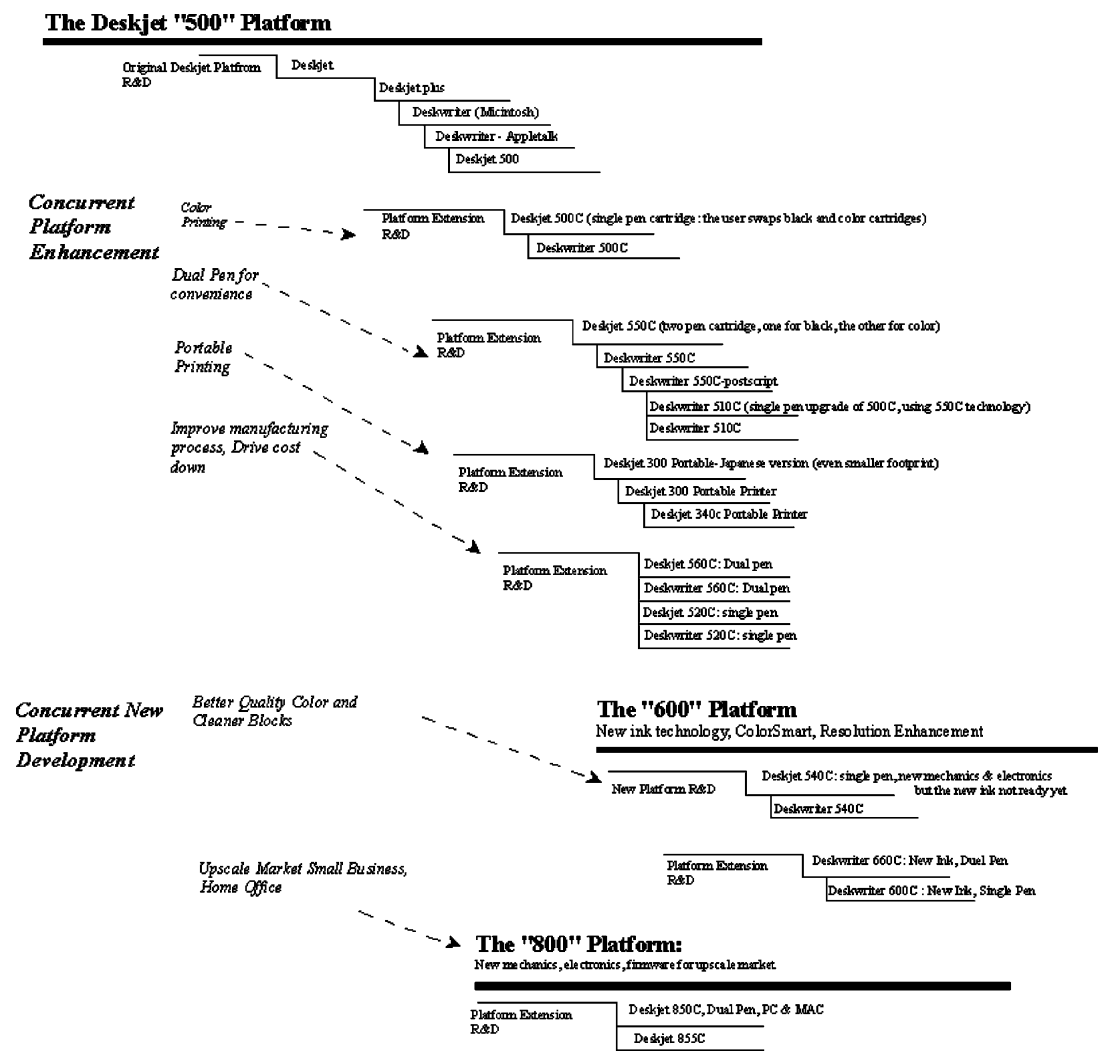

Figure 1. The product family map for HP's inkjet printer. (Source: Meyer, M.H. and Lehnerd, A.P., 1997, The Power of Product Platforms, New York: Free Press).

engineering effort. However, it is important to note that HP originally had planned to launch the "600" platform to replace the "500" platform but was actually forced to continue with the "500" platform for a short period. This was because HP could not finish the Platform "600" work on time (Meyer and Lehnerd 1997). HP started developing Platform "800" almost at the same time as Platform "600." The summary of the HP case is simple-HP wanted to address many issues such as reducing cost, updating technology, and addressing the dynamic customer needs using a solid product planning strategy. Nevertheless, the journey for HP was fraught with uncertainty and risk arising from various sources. We argue that the competitiveness of any company is based not only on its current and future product offerings but also on the optimum time frame of those product offerings in the marketplace. In this 
article, we consider two important product planning decisions as listed below:

1. Product variant decisions: Product variants are derived from the product platform. Managers must decide on the optimal time frame to offer each product variant in the marketplace to make sustainable profits. The managers are also expected to make decisions such as upgrading/contracting/abandoning the existing product variants.

2. Platform decisions: The new product development (NPD) team must make a decision to select a concept platform to generate future product variants. Typically, the challenge is to select one or more platform concepts from several possible alternatives.

Though the anatomy of NPD and platform development is well researched (Pugh, 1996; Pahl and Beitz, 1996; Meyer and Lehnerd, 1997; Ulrich and Eppinger, 2000; Krishnan and Gupta, 2001; van Vuuren and Halman, 2001; Antonsson and Cagan, 2001; Otto and Wood, 2001; Cagan and Vogel, 2002; Shetty, 2002; Otto and Hölttä-Otto, 2005; Simpson, Siddique, and Jiao, 2005; Suh, 2005; Halman, Hofer, and van Vuuren, 2006), the evaluation of product plans is not well established in practice. A question that is not well answered is how investments during the early stages of the project, which bet on the future uncertainties in the market, technological outcomes of $\mathrm{R} \& \mathrm{D}$, competition from the rival companies, etc., are to be evaluated for their expected financial performance. Halman et al. (2006) discussed the platform-based product family development practices at three companies (namely, ASML, Skil, and SMI). The perceived risks related to platform-based product family development were identified for these three companies. Halman et al. (2006) noted that decision-making tools involving risks in platform development are needed. Clearly, if uncertainties are not included in the evaluation process, a company may fail to make the right strategic choice, which may result in loss of the market share and profits. We term this situation myopic syndrome, where companies fail to foresee the future optimally.

Traditional static analysis such as the discounted cash flow (DCF), net present value (NPV), or internal rate of return (IRR) fail to capture comprehensive "what if" scenarios. It is important to note that the NPV calculations do not consider uncertain events that may occur in the future. Many works identify such shortcomings and show that negative NPV values may sometimes change if flexibility is considered in the evaluation process (Leslie and Michaels, 1997; Amram and Kulatilaka, 1999; Brealey and Myers, 2000). The static nature of the NPV methodology does not allow decision makers to react to uncertain events during the course of the NPD project (Geppert and Roessler, 2001). 
In an attempt to evaluate the outcomes of NPD projects, Meyer and Lehnerd (1997) proposed the concept of platform efficiency and effectiveness. The platform efficiency is measured as a ratio of the cost of developing derivative products to the cost of developing a platform. The platform efficiency can also be measured as a ratio of the revenue from a particular product variant to the development cost of the product variant. Meyer and Lehnerd (1997) also proposed other methods such as technological competitive responsiveness, profit potential, etc., to measure the outcome of the NPD projects. While these metrics provide a good context to determine when a product platform should be deployed, they do not consider different uncertainties associated with the platform development and launching of derivative products in the marketplace.

Clearly, there is a need for strategic product planning decision-making tools to include uncertainties and incorporate the needed flexibility in the decision-making process (in order to make decisions such as delaying or pulling back a product variant from the marketplace if a situation warrants). We treat product variants as physical assets of companies and propose that strategic decisions for product planning be taken by considering uncertainties. The real options analysis can provide decision-makers with the flexibility to understand the decision rules at different points of a project timeline (Copeland and Weiner, 1990; Nicholas, 1994).

In this study, we seek to develop a systematic methodology to address the following research questions.

- Decision 1: How long should the company offer its existing product variant? When should the company abandon/scale up/scale down the existing product variant?

- Decision 2: Out of the several possible competing concept product platforms, which product platform should be selected?

Although in this article we treat Decision 1 and Decision 2 as two different problems, there is an inherent connection between them. Decision 1 is applicable to cases where the platform is already in existence and the existing product variants are to be evaluated. Decision 2 is applicable to cases where a new platform development is being undertaken. In a way, Decision 2 can be viewed as a superset of Decision 1. In order to evaluate Decision 2, Decision 1 evaluation for each of the potential product variants has to be conducted.

\section{Real Options}

Myers (1977) was the first to view uncertain factors as future options and coin the term real options. The inspiration of real options comes from the 
financial world where an option gives the holder the right but not the obligation to exercise on or before the expiration date (Amram and Kulatilaka, 1999; Brealey and Myers, 2000). Similarly, a company has the right to act on any strategic choice (or option) on its product variant (right to introduce a new product variant, abandon existing one, extend a product variant, etc.). Nevertheless, it is not an obligation for the company to act on these strategic choices (options). The basic tenet of real options is that uncertainty may create value and should not be ignored (Amram and Kulatilaka, 1999; Herath and Park, 1999; Brealey and Myers, 2000; Park and Herath, 2000). Research on options valuation first started in the late 1970s with the publication of papers by Black and Scholes (1973) and Merton (1973). Since then, there have been many contributions toward the valuation of option instruments (Dixit, 1989; Dixit and Pindyck, 1994, 1995; Trigeorgis, 1988). Dixit (1989) and Dixit and Pindyck (1994, 1995) contributed sophisticated research tools to evaluate investment under uncertainty. The binomial method by Trigeorgis $(1991,1997)$ can link the decision tree (Smith and Nau, 1995; Brealey and Myers, 2000; Brandao and Dyer, 2003; Mun, 2002) to the value of product variant and platform development projects at different points of time. The binomial method remains one of the best evaluation techniques for real options since it links the decision-making process with an evaluation methodology and at the same time is easy to implement.

Few engineering firms (for example, $\mathrm{ABB}$ ) and biotechnology firms have already employed real options framework in their investment decisionmaking process (Pine, 1993; Kellogg and Charnes, 2000). Real options analysis has also been applied to numerous fields such as construction (Ramirez, 2002), pharmaceutical R\&D (Copeland and Antikarov, 2001; Mun, 2002), project evaluation (Huchzermeier and Loch, 2001), real estate (Titman, 1985; Williams, 1991), and system planning and design (de Neufville, 2003). Lint and Pennings (2003) discussed the application of real options to the NPD process by highlighting various stages such as idea generation, R\&D, validation, etc. Lim et al. (2005) and Jiao, Kumar, and Lim (2006) also applied real options methodology to evaluate the flexibility of product family architecture. Jiao et al. (2006) described how real options can be used to evaluate product variety generation methods. They, however, do not discuss the specific problem related to product planning. Our contribution lies in introducing a comprehensive methodology for evaluating the platform-based product planning road maps. The proposed methodology will address the issues concerned with planning embedded with future uncertainties and will help decision-makers to make intelligent decisions during the course of product planning. 


\section{Real Options Modeling for Product Planning}

In this article, we use the real options technique and a decision tree approach to make decisions at different points of time in the product planning process. Introducing strategic options evaluation in the decision process will incorporate the managerial flexibility such as abandoning the project if the conditions are not favorable or even extending the project life or upgrading the product features if the market conditions encourage such an action. Also, when evaluating several different strategic platform options, the proposed real options method considers several uncertainties that are unaccounted for in the traditional evaluation tools. In this article, it will be shown that the application of real options methodology in the product planning evaluation will bring flexibility in the decision-making process. Such flexibility will not only boost the investor's confidence in a project but also will ensure that the most promising project is selected. Table 1 depicts the basic assumptions of options valuation and how they have been interpreted in the financial and product planning application domains. Table 2 illustrates how the basic parameters of the financial options have been interpreted for the product planning application domain.

In a continuous time scenario, the number of decision nodes in the simulation or the decision tree is infinite. A continuous time model approach for options will produce stochastic differential equations that would yield a Black-Scholes type of closed form solution (Mun, 2002). Jiao et al. (2006) developed a partial differential equation system to evaluate real options on product family design. Admitting that it is "almost impossible" to get an analytical solution easily, Jiao et al. (2006) used numerical methods to find the real options value. It is not only difficult (and time consuming) to solve the stochastic differential equations, but it also raises concerns over the solution approximations and analogy used in the real options model. Also, since it is easier to approximate different development outcomes in NPD cycle, a decision tree approach which can accommodate such approximation is more suitable than the Black-Scholes model or the simulation methodology. In this article, we use a combination of binomial and multinomial methods to build the decision tree to evaluate the product planning options. Our study is influenced by the works of Cox, Ross, and Rubenstein (1979), Amram and Kulatilaka (1999), and Copeland and Antikarov (2001).

\section{Identify Strategic (Real) Options on Product Planning}

In this section, we identify some of the typical strategic decisions (on strategic choices or options) that are made during the product planning process. 
Table 1. Options evaluation methodology

\begin{tabular}{|c|c|c|}
\hline $\begin{array}{c}\text { Basic assumptions of } \\
\text { options valuation }\end{array}$ & Financial options & Real options for product planning \\
\hline $\begin{array}{l}\text { Stochastic behavior of } \\
\text { the price of the } \\
\text { underlying asset }\end{array}$ & $\begin{array}{l}\text { Market price of the } \\
\text { underlying asset is } \\
\text { stochastic in nature. The } \\
\text { price of the underlying can } \\
\text { change (random increment } \\
\text { or decrement) for each } \\
\text { small interval of time with } \\
\text { a certain probability. Such } \\
\text { stochastic phenomenon } \\
\text { can be mathematically } \\
\text { modeled as geometric } \\
\text { Brownian motion (Hull, } \\
\text { 2006) }\end{array}$ & $\begin{array}{l}\text { The future revenue generated from } \\
\text { the product variants can change } \\
\text { with certain probability } \\
\text { depending on the economic and } \\
\text { business conditions during that } \\
\text { time period. Such changes in the } \\
\text { future revenue are stochastic in } \\
\text { nature. Therefore, for modeling } \\
\text { purposes, the cash flow stream } \\
\text { generated by the product } \\
\text { variants is assumed to have the } \\
\text { properties of geometric } \\
\text { Brownian motion }\end{array}$ \\
\hline $\begin{array}{l}\text { Continuous } \\
\text { (Black-Scholes } \\
\text { Model) vs. discrete } \\
\text { (binomial tree) setup }\end{array}$ & $\begin{array}{l}\text { Both types of evaluations are } \\
\text { common in the financial } \\
\text { world }\end{array}$ & $\begin{array}{l}\text { Product planning decisions are } \\
\text { usually made at discrete time } \\
\text { intervals. A combination of } \\
\text { binomial and multinomial } \\
\text { methods is used to build the } \\
\text { decision tree }\end{array}$ \\
\hline Type of options & $\begin{array}{l}\text { American or European } \\
\text { options }\end{array}$ & $\begin{array}{l}\text { American type of options are } \\
\text { considered as it would give the } \\
\text { flexibility to exercise the option } \\
\text { at any time during the } \\
\text { investment horizon. European } \\
\text { options can be exercised only at } \\
\text { the time of maturity and } \\
\text { therefore such options will not } \\
\text { bring the needed flexibility to } \\
\text { the decision-maker }\end{array}$ \\
\hline $\begin{array}{l}\text { Dividend paying or } \\
\text { non-dividend paying }\end{array}$ & $\begin{array}{l}\text { Several studies have been } \\
\text { published to incorporate } \\
\text { the dividends paid in the } \\
\text { options valuation } \\
\text { methodology }\end{array}$ & $\begin{array}{l}\text { Non-dividend paying case is } \\
\text { assumed as there are no cash } \\
\text { inflows during the development } \\
\text { phase (during the development } \\
\text { phase, we assume there are only } \\
\text { cash outflows) }\end{array}$ \\
\hline
\end{tabular}

As mentioned earlier, this study considers the following two decisions: product variant decisions and product platform decisions.

\section{Decision 1: Product Variant Decision}

The product planning process entails two key parts- the first part is concerned with the existing product variants, and the second part is concerned 
Table 2. Basic parameters to evaluate financial options and real options

\begin{tabular}{ll}
\hline Financial options & Real options in the context of product planning \\
\hline Stock price & $\begin{array}{l}\text { Cash flow generated by the product variants } \\
\text { Exercise price }\end{array}$ \\
$\begin{array}{l}\text { Cost of adopting a particular strategic decision } \\
\text { Implied volatility in the projected cash flows and } \\
\text { various uncertainties in the product } \\
\text { development processes }\end{array}$ \\
\hline
\end{tabular}

with the future product variants and corresponding platforms. The product variant decision contains the following two questions:

- How long should the company offer its existing product variant?

- When should the company abandon/scale up/scale down its existing product variant?

Since the product variant is already being offered in the market, the decision whether to continue with or abandon the product variant or to upgrade the product variant with new features will depend on the future market outlook. If the future market conditions appear bleak, the obvious question will be how soon the product variant should be abandoned. The abandonment of the product variant can be through gradual sales contraction or through immediate abandonment. Clearly, all the above possible decisions are aimed to generate maximum flexibility from uncertain market conditions to the decision-makers.

In terms of real options terminology, we identify decision options with respect to the above-mentioned questions. The decision options are abandon option (an option that helps to find the optimal timing for abandoning the product variant), contract option (an option that lets the company contract their business before completely abandoning their product variant), upgrade option (an option to decide whether or not to upgrade the product variant with new features and technology), and unexercise option (an option that lets the company continue with the existing product variant provided that there is enough potential for positive payoff). Upgrading the current product variant may require some investment. An unexercise option would mean that the original plan to offer the product variant is left untouched.

The American put option gives the holder the right to sell the underlying asset on or before the maturity date (Hull, 2006). The abandonment option also gives the decision-maker the right but not an obligation to call off the project if the situation is not favorable. Therefore, the abandonment option is modeled as an American put option. The exercise price for the abandonment option would be the salvage value or the cost savings for the 
company arising from abandoning the project. The abandonment option will be deep in value when the value of the underlying asset is less than the exercise value. Similarly, a contract option can be modeled as an American put option, as it will give the decision-maker the right but not the obligation to contract the project. The exercise price for the contract option would be the cost savings by contracting the product variant or the salvage value that is generated by retiring the product variant.

An American call option gives the holder the right but not an obligation to buy an underlying asset by paying the exercise price (Hull, 2006). The upgrade option gives the decision-maker the option to upgrade the current product variant by investing more resources. Therefore, the upgrade option is modeled as an American call option. The exercise price in this case is equivalent to the investment made to upgrade the product variant. In this case, the decision-maker will exercise this option if the exercise cost is less than the original value of the underlying asset. Similarly, the unexercise option is modeled as an American call option. The exercise price for the unexercise option is nothing but the cost incurred by continuing the same product variant.

Table 3 summarizes the different product planning decisions and corresponding real options.

\section{Decision 2: Product Platform Decision}

The product planning process includes the selection of the best product platform concept that will be deployed to generate the product variants.

\section{Table 3. Real options modeling}

\begin{tabular}{|c|c|c|c|}
\hline Decisions to make & Real options & Modeled as & Exercise price \\
\hline $\begin{array}{l}\text { Abandoning the current } \\
\text { product variant }\end{array}$ & $\begin{array}{l}\text { Abandonment } \\
\text { option }\end{array}$ & $\begin{array}{l}\text { American } \\
\text { put }\end{array}$ & $\begin{array}{l}\text { Salvage value or the cost } \\
\text { savings for the company } \\
\text { arising from abandoning } \\
\text { the product variant }\end{array}$ \\
\hline $\begin{array}{l}\text { Contracting the current } \\
\text { product variant }\end{array}$ & Contract option & $\begin{array}{l}\text { American } \\
\text { put }\end{array}$ & $\begin{array}{l}\text { Cost savings by contracting } \\
\text { the current product } \\
\text { variant or salvage value } \\
\text { from the product variant }\end{array}$ \\
\hline $\begin{array}{l}\text { Upgrading the current } \\
\text { product variant }\end{array}$ & Upgrade option & $\begin{array}{l}\text { American } \\
\text { call }\end{array}$ & $\begin{array}{l}\text { Investment necessary to } \\
\text { upgrade the current } \\
\text { product variant }\end{array}$ \\
\hline $\begin{array}{l}\text { Continuing with the same } \\
\text { product variant }\end{array}$ & Unexercise option & $\begin{array}{l}\text { American } \\
\text { call }\end{array}$ & $\begin{array}{l}\text { Cost to continue with the } \\
\text { same product variant }\end{array}$ \\
\hline $\begin{array}{l}\text { Making new investments } \\
\text { on new product } \\
\text { concept design and } \\
\text { implementation }\end{array}$ & $\begin{array}{l}\text { Compound rainbow } \\
\text { option }\end{array}$ & $\begin{array}{l}\text { American } \\
\text { call }\end{array}$ & $\begin{array}{l}\text { Investment needed at } \\
\text { different stages }\end{array}$ \\
\hline
\end{tabular}


Clearly, the product platform decision contains the following questions:

- Out of several possible competing product platforms concepts, which product platform should be selected?

- Should the investment for the new platform development work be continued and proceed to the next development phase?

Answering the questions posed above will determine the most economically viable platform with technical risk considerations. The decisionmaking would not only depend on the market values of the individual product variants to be derived from the platform in question but also on the uncertainties involved in the platform development phase and implementation phase. As uncertainty changes from one phase of development work to the next phase, the proposed methodology will help decision-makers to understand whether further investment should be committed to move to the next phase of the development work. In this article, we consider the following three different uncertainties associated with the platform development activity:

- Technical uncertainty (uncertainty whether the $R \& D$ will be successful to produce the desired platform and variants)

- Market uncertainty (uncertainty whether the business for a particular product variant will grow or decline)

- Implementation uncertainty (uncertainty whether the company will be able to offer all the desired product variants over the platform life)

Since the platform development process is divided into different stages, the value of a downstream development stage is dependent on the success of its upstream development stage. It is assumed that experienced project personnel will assign probabilities to technical uncertainties and the implementation uncertainties. These probabilities are subjective in nature. It is also assumed that the market uncertainty can be estimated by using market research tools.

A compound rainbow option is defined as an option on an option (compound option) with multiple sources of uncertainty (rainbow option; Mun, 2002). In a compound rainbow option, the underlying asset (product variants generated from a given platform) is driven by multiple sources of uncertainties and the value of one option is contingent upon the upstream development phase. This type of option is very common in pharmaceutical R\&D evaluation. Since at every stage of the development and implementation phase the company will have the right to abandon or continue with further investment to the next phase, we model such a decision as an American option. The strike price for this option would be the additional investment needed at each stage of the platform development process. 


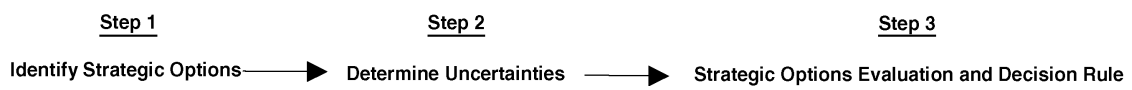

Figure 2. Proposed methodology.

\section{Proposed Methodology}

The proposed methodology is shown in Figure 2. In our methodology, the uncertainties and risks involved in the product development and planning process have been integrated into the evaluation process for better decision-making. We apply real options tools to implement the decisionmaking process. The implementation of the proposed methodology will be discussed later in this article using an illustrative example case. Each of the steps shown in Figure 2 is briefly described in the following paragraphs.

\section{Step 1: Identify Strategic Options}

Since uncertainty can create future opportunities (or options), the decisionmakers should carefully understand the context and then identify the various options available to them. Several different kinds of real options such as the abandon option, contract option, etc., have been discussed in previous sections. Readers are refered to the study by Amram and Kulatilaka (1999) for a comprehensive discussion of real options. Once the strategic options are identified, the practitioners must determine the economic values associated with those options.

\section{Step 2: Determine Uncertainties}

This is the most important and difficult part of the real options evaluation methodology. The tools to quantify different kinds of uncertainties are not the subject of this article. First and foremost, major uncertainties at each stage of the product planning process must be identified and estimated. This will help us to understand the effects of such uncertainties on the cash flows and static NPVs. In this article, the technical uncertainty, market uncertainty, and project implementation uncertainty are identified as three major sources of uncertainties in product planning. We assume that these uncertainties are uncorrelated in nature.

We also consider all future cash flows as inputs while taking uncertainties into account since they impact the economic value of the product variant. The future cash flows generated by the product variants determine the value of the product platform. In this article, the market uncertainties are partially captured through the volatility in the future cash flows by simulating the traditional static NPV of the product variant (using Monte Carlo simulation). 


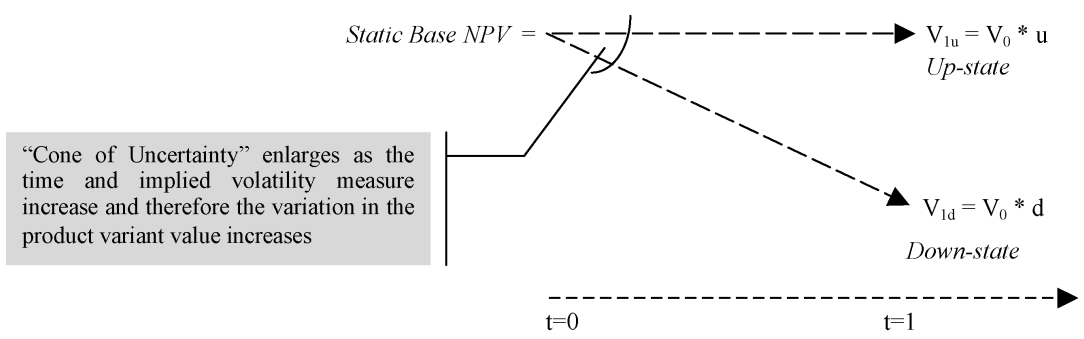

Figure 3. Constructing the asset value tree.

We use the uncertainty measure to create the underlying asset (product variant) value lattice. The underlying asset value lattices indicate how the economic value of the underlying asset can vary with time and uncertain events. Such variation expands the "cone of uncertainty" and enhances the value of the real options on the underlying assets.

To build the asset value lattice for Decision 1, the uncertainties are incorporated with the assumption that the value of the asset (product variant) follows geometric Brownian motion. The asset value lattice for Decision 1 is created from market related uncertainty. The value of the product variant can move up or down based on the volatility of the future cash flow. In this article, the up-state and down-state factors are denoted by $u$ and $d$, respectively. These up-state and down-state factors are used to build the binomial lattice (refer to Figure 3), starting with the static base NPV.

The up-state factor $(u)$ and the down-state factor $(d)$ are represented as follows:

$$
\begin{aligned}
& u=e^{\sigma \sqrt{\Delta t}} \\
& d=e^{-(\sigma \sqrt{\Delta t})}
\end{aligned}
$$

where $\sigma=$ implied volatility in the future cash flows and $\Delta t=$ time increment in the decision lattice.

As shown in Figure 3, the lattice starts with the static net present value, $V_{0}$, of the underlying asset at $t=0$. The up-state and down-state factors help us to determine the value of the product variant at different economic conditions, which is represented by the nodes. Multiplying $V_{0}$ by the upstate and down-state factors will produce the up-state value $\left(V_{1 u}\right)$ and the down-state asset value $\left(V_{1 d}\right)$, respectively, at $t=1$. We derive the rest of the values in the binomial lattice in a similar fashion.

Since Decision 2 involves market, technical, and other product development-related uncertainties, we build an event tree by combining the asset value lattices for different NPD outcomes. The asset value 
lattices for different NPD outcomes (such as outstanding platform or mediocre platform) are built using the same methodology as described for Decision 1.

\section{Step 3: Strategic Options Evaluation and Decision Rule}

Option Evaluation for Decision 1: The first objective is to find the option values at each node and then find the net options value (NOV) of the product variant at the initial node (at $t=0$ ). Like any other options problem, we start evaluating the decision tree from the terminal nodes and proceed to the intermediate nodes of the decision lattice. At the terminating nodes, the unexercise option value is same as the market value of the underlying node.

The first task is to evaluate the unexercised option. The general methodology to evaluate the unexercise option at the intermediate nodes adopted in this article is the risk-neutral evaluation methodology that was originally developed by Cox et al. (1979). Using the risk-neutral evaluation methodology, the value of the unexercise option (value of the product variant adjusted for flexibility) is found by using Equation (3). The value of $f$ indicates the value the product variant will have if left untouched.

$$
f=\left(f_{t u} p^{*}+\left(1-p^{*}\right) f_{t d}\right) /\left(1+R_{f}\right)^{\Delta t}
$$

where

$f=$ Value of the unexercise option at the intermediate nodes

$f_{t u}=$ Value of the decision made in the up-state lattice

$f_{t d}=$ Value of the decision made in the down-state lattice

$p^{*}=$ Risk-neutral probability $=\frac{\left(1+R_{f}\right)-d}{u-d}$

$u=\mathrm{Up}$-state factor

$d=$ Down-state factor

$R_{f}=$ Risk-free rate for that period

$\Delta t=$ Time step (assumed to be 1 in this article)

Clearly, the value of the unexercised option is the risk-adjusted present value based on the values of the decisions made at the previous nodes. Once the evaluation is made at the terminal nodes, we proceed to the intermediate nodes. The values of the product variant options at the intermediate nodes are calculated in a similar fashion.

The Decision Rule for Decision 1: The decision rule is to select the option with highest net payoff or value. The optimal decision is based on the economical information available at a particular node in the decision tree. Companies will make an investment decision only when the payoff from the strategic action is greater than the costs incurred for that decision. The 
strategic options considered at each node are mutually exclusive; exercising one option does not depend on other option. Since all the strategic options embedded in the decision process are mutually exclusive, we select the strategic product variant option that produces the highest payoff. The payoff at different nodes for Decision 1 is found as follows:

Decision Value $=$ Max (Payoffs from available options)

$$
=\text { Max (Unexercise option Payoff, Abandonment Payoff, }
$$

Contracting Payoff, Extension Payoff)

Option Evaluation for Decision 2: We integrate three different kinds of uncorrelated uncertainties - market uncertainty, technical uncertainty, and implementation uncertainty in a multinomial decision tree and follow the same risk-neutral evaluation methodology as described earlier. Since we assume the uncertainties to be uncorrelated, the joint probability of the uncertain events (or multinomial probability) occurring together is measured as the product of the individual probabilities. Table 4 shows how these probabilities are calculated for each case. Once the probability measures are found, then we can apply the risk-neutral methodology to find the option value.

At the terminal nodes, the options value is the difference between the market value of the underlying asset adjusted for implementation uncertainty and the required investment. The option is selected if this intrinsic

Table 4. Probability calculation

\begin{tabular}{lcc}
\hline Time period & Binomial probability & Multinomial probability \\
\hline Between $t=0$ and $t=1$ & $P(S)$ & $P(S U)^{+}=P(S)^{*}(P U)$ \\
& $P(F)$ & $P(S D)=P(S)^{*} P(D)$ \\
& $P(U)=p^{*}$ & $P(F U)=P(F)^{*} P(U)$ \\
& $P(D)=1-p^{*}$ & Sum $=1$ \\
Between $t=1$ and $t=2$ & $P(D)=P(D)^{*} P(D)$ \\
& $P(O)$ & $P(O U)=P(O)^{*} P(U)$ \\
& $P(N P)$ & $P(O D)=P(O)^{*} P(D)$ \\
& $P(U)=p^{*}$ & $P(M D)=P(M) * P(U)$ \\
& $P(D)=1-p^{*}$ & $P(N U)=P(N) * P(U)$ \\
& & $\operatorname{Pum}=1$ \\
& & Sum $=1(D) * P(D)$ \\
\hline
\end{tabular}

+ Please note that the multinomial probability such as $P(S U)$ is read as probability of successful R\&D and upward market. For nomenclature, refer to appendix 1. 
value is positive. The real option value at the intermediate nodes can now be calculated following a similar methodology described previously for Decision 1. The real options values $C$ at different intermediate nodes are given by a general formula as shown in Equation (5).

$$
C=\left(\sum p_{i}^{\prime} C_{t i}\right) /\left(1+R_{f}\right)^{\Delta t}
$$

where

$C_{t i}=$ Value of the decisions made at the end of the time period

$p_{i}^{\prime}=$ Multinomial probability respective to $C_{t i}$ (as calculated in Table 4)

$R_{f}=$ Risk-free rate for that period

$\Delta t=$ Time step (assumed to be 1 in this article)

The Decision Rule for Decision 2: To select the best platform development project, we apply the same principle that is followed in the traditional project evaluation methodologies. After each of the proposed concept platforms are evaluated, we select the product platform with highest flexibility value or NOV. The NOV is defined as the option value found at $t=0$ of the multinomial decision tree built for Decision 2. With this approach, one can overcome the shortcomings offered by NPV or IRR methods while choosing the best platform from a set of potential platforms.

The second question in this section seeks to understand whether to proceed with the platform development work into subsequent phases given that some amount of work has been accomplished in the previous development stage. The decision tree starts by evaluating the terminal nodes. At the terminal nodes in the decision tree, the firm decides whether to invest money for the final phase of product platform development process. These nodes represent the valuation for production implementation uncertainty. The firm invests only if the market value is higher than the investment value. Next, the decision tree moves to the intermediate nodes. At the intermediate nodes, we find the value of the product platform option at that node using the risk neutral evaluation methodology and compare that with the amount needed to invest to proceed to the next phase of the NPD process. The decision to invest is made if and only if the option value is positive and greater than the investment amount. Mathematically speaking, the decision value is calculated using the following rule:

Decision Value $=$ Max [0, (Option Value - Investment Amount $)]$

Decision Rule: If the Decision Value $>0$,

then invest at that node; otherwise, do not invest. 
Next, the working of our methodology is illustrated using an example of XYZ Corporation's product planning problem.

\section{Example Case}

Corporation XYZ faces a dilemma while making the investment decisions related to strategic product planning. Their existing product variant \#2 generates positive cash flows. However, the upper management thinks that product variant \#2 should be updated to reflect the changing needs of the consumer. The updated product variant will help them to gain market share and competitive advantage in the future. The XYZ Company is also interested in launching a new platform and eventually generating new product variants. The design team identified three concept platform development projects (concept platform \#1, concept platform \#2, and concept platform \#3). Each of these platform development projects has the potential to generate three different product variants at different points in time. The cost and uncertainties involved with all the concept platform development projects are different, and the expected payoffs of the associated product variants are different as well. To develop concept platform \#1, an investment of $\$ 25 \mathrm{M}$ is required in the first year followed by an investment of $\$ 100 \mathrm{M}$ in the second year. At the end of second year, if the outcome of the platform development project is outstanding, then the company will have the option to further invest $\$ 250 \mathrm{M}$ for production setup and related expenditures for product launch. The estimated static market value of the product platform is found by adding up the estimated static present value of the future cash flows for the individual product variants derived from the platform. If the $R \& D$ results are outstanding, then the developed product platform will have an estimated static market value of $\$ 900 \mathrm{M}$ (at $t=0$ ). If the $\mathrm{R} \& \mathrm{D}$ results are mediocre, then the estimated static market value will be $\$ 200 \mathrm{M}$. The company predicts that the business will grow at $20 \%$; however, it may also decline at a rate of $20 \%$. For brevity purposes, we have assumed that the NOVs for concept platform \#2 and concept platform \#3 are $\$ 0.23 \mathrm{M}$ and $\$ 2.91 \mathrm{M}$, respectively. In this case example, we will focus on the procedure to compute the NOV for concept platform \#1 only. Also, the company cannot abandon its existing product line immediately. It plans to gradually abandon the current product line. Figure 4 shows the product plan for the XYZ Company.

Some of the economic details are presented below.

1. The current product variant \#2 can be deployed for a maximum of 6 years starting today at $t=0$; i.e., it has a shelf life of 6 years. 


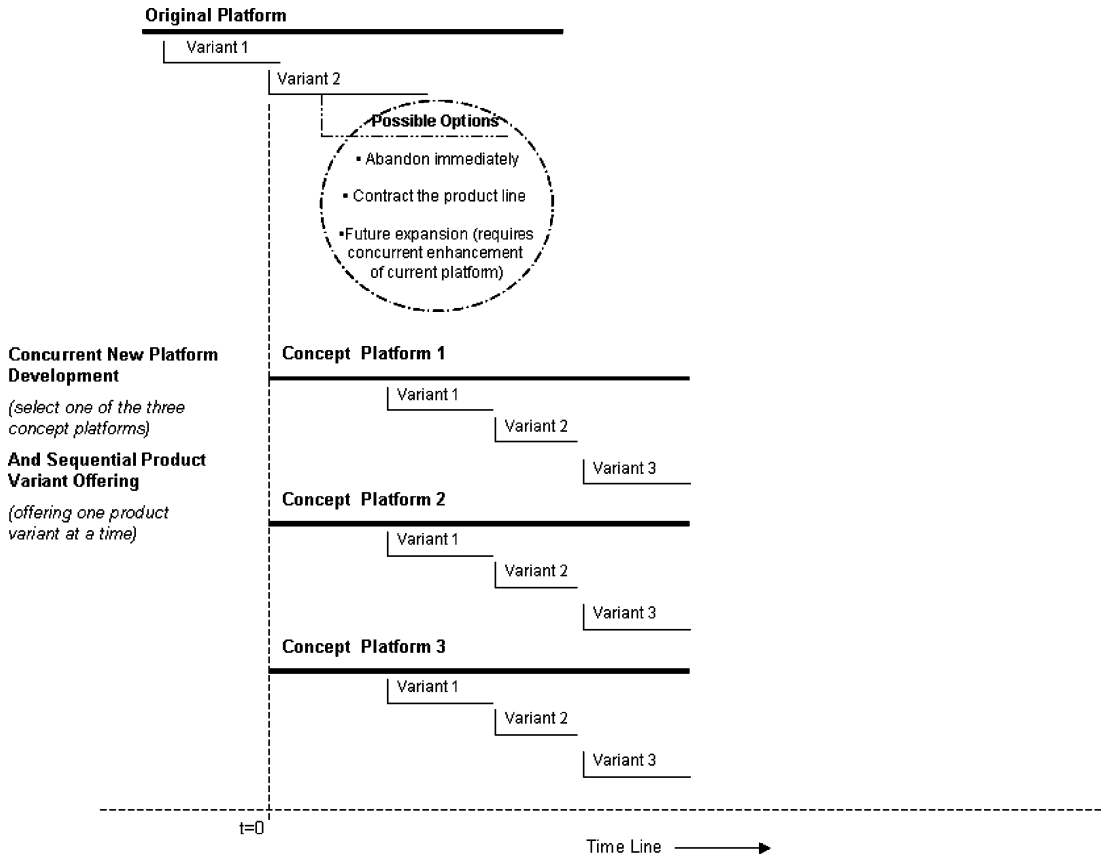

Figure 4. Product planning at XYZ Corporation.

2. The current variant \#2 needs to be technically upgraded and the cost to upgrade is reflected in the static NPV (traditional NPV). Traditional static NPV for the current product variant is $\$ 503.99 \mathrm{M}$.

3. The cash flows are discounted at a weighted average cost of capital (WACC) of $15 \%$, and the risk-free rate is $5 \%$.

4. Table 5 represents the projected cash inflows that are assumed for abandoning, contracting, or upgrading the product variant for different time periods.

Table 5. Revenue/costs associated with exercising options (in million dollars)

\begin{tabular}{lrrrrrr}
\hline & $t=0$ & $t=1$ & $t=2$ & $t=3$ & $t=4$ & $t=5$ \\
\hline Abandoning salvage value & 400 & 400 & 400 & 400 & 460 & 460 \\
Contracting salvage value & 310 & 300 & 300 & 290 & 250 & 250 \\
Investment to upgrade & -300 & -300 & -300 & -400 & -660 & -700 \\
\hline
\end{tabular}




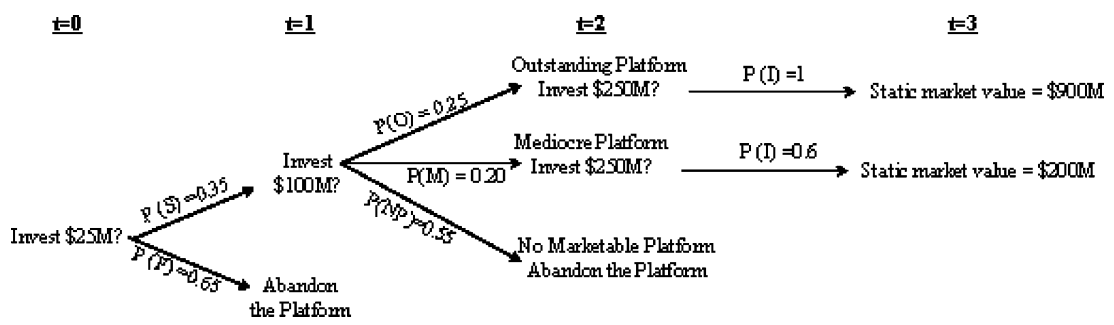

Figure 5. Event tree for concept platform \#1 development project.

5. The company can contract the product variant $\# 2$ sales by $60 \%$ if they choose to exercise the contract option. It is also assumed that upgrading the product line can increase the revenue by $10 \%$.

The company's past 10-year record indicates that the typical success rate to produce an outstanding platform is $25 \%$ and a mediocre platform is $20 \%$. The company failed $55 \%$ of the times to produce a platform with marketable product variants. In addition, the success rate to complete the first round of platform development work is $35 \%$. The event tree for the platform development project is shown in Figure 5.

\section{Decision 1: Evaluating Existing Product Variant}

\section{Step 1: Identify Strategic Options}

For the example case, we consider the following options to be embedded in the decision tree: abandon option, contract option, upgrade option, and

Table 6. Binomial lattice-product variant economic values (in million dollars)

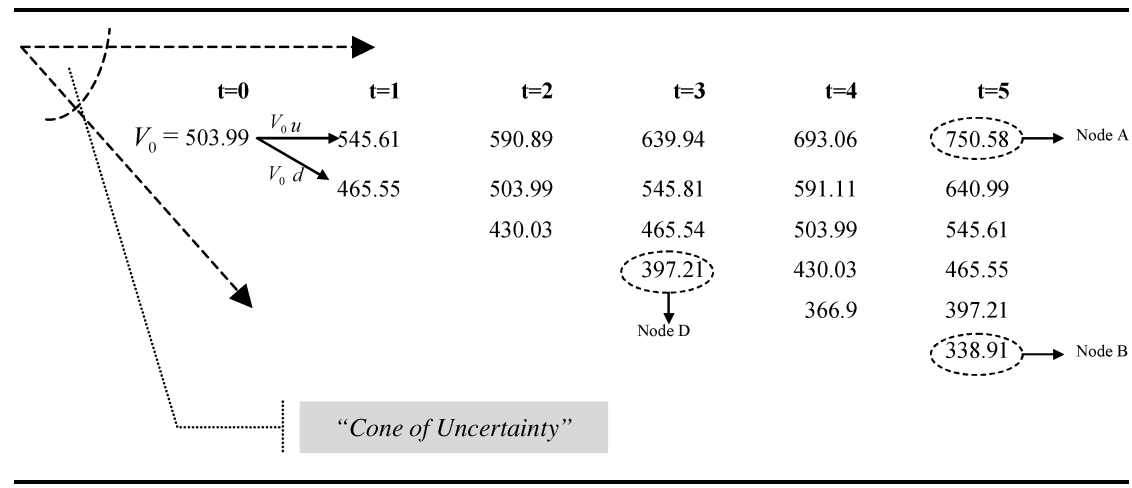


unexercise option. The next step is to determine the uncertainty of the projected cash flows of the product variants.

\section{Step 2: Determining Uncertainties}

Monte Carlo simulation is used to determine the volatility of the projected cash flow. The traditional NPV of the project and the revenue stream is simulated using Monte Carlo simulation. We use the information that the business would either grow or decline by $20 \%$ in the simulation model and find the standard deviation at $90 \%$ confidence level. For the example case presented here, the standard deviation of the revenue stream obtained by the simulation is $\$ 41.82 \mathrm{M}$. The implied volatility $(\sigma)$ is estimated to be $7.93 \%$. The full simulation results are not shown, keeping in the mind the article length and the fact that Monte Carlo simulation is a well-established technique.

Next, the binomial lattice representing the event tree is created starting with the static net present value, $V_{0}$, of the underlying asset at $t=0$. Multiplying $V_{0}$ by the up-state and down-state factors will produce asset values at $t=1$ (refer to Table 6). We derive the rest of the values in the binomial tree in a similar fashion. Table 6 represents product variant economic values at various points in time.

\section{Step 3: Strategic Option Valuation and Decision Rule}

The company will make a strategic business decision when the payoff from the strategic action is greater than the costs incurred. The evaluation starts at the terminal node of the decision tree (nodes representing year $t=5$ in our example) and proceed to the intermediate nodes of the decision tree.

\section{Evaluation at the Terminating Nodes in the Binomial Decision Tree}

To find the optimal decision and its value made at a particular node in the terminal year, the payoffs from the individual options are calculated at that particular node. The decision value at that the node is found as follows:

Decision Value $=$ Max (Unexercise option payoff, Abandon option payoff, Contract option payoff, Upgrade Option payoff)

For example, we consider Node A (refer to Table 6) and find the optimal decision value. The calculations for Node A are shown in Table 7.

As shown in Table 7 , the value of the decision at Node A is $\$ 750.58 \mathrm{M}$, and the strategic option to choose is the unexercise option. Therefore, at Node A, the maximum value can be attained if the company decides to continue with the current product variant. Such a decision will generate a payoff of $\$ 750.58 \mathrm{M}$ to the company's cash flow at $t=5$. The product variant gained this value because of several upward movements in the market. Node B represents a point in the decision tree where the asset 
Table 7. Value of the decision made at node A

\begin{tabular}{|c|c|c|c|}
\hline $\begin{array}{r}\text { Type of } \\
\text { option }\end{array}$ & Option information & Payoff from the option & $\begin{array}{l}\text { Decision value } \\
\text { at node } A\end{array}$ \\
\hline $\begin{array}{l}\text { Unexercise } \\
\text { option }\end{array}$ & $\begin{array}{l}\text { Continue with the } \\
\text { product variant }\end{array}$ & $\begin{array}{l}\$ 750.58 \mathrm{M} \text { (Since it } \\
\text { does not cost to } \\
\text { continue with the } \\
\text { same product } \\
\text { variant at this node) }\end{array}$ & $\begin{array}{c}\text { Max (payoffs from the } \\
\text { available options) }= \\
\$ 750.58 \mathrm{M} \text { (Select } \\
\text { unexercise option) }\end{array}$ \\
\hline $\begin{array}{c}\text { Abandon } \\
\text { option }\end{array}$ & $\begin{array}{l}\text { Abandoning the product } \\
\text { variant immediately } \\
\text { will fetch } \$ 400 \mathrm{M} \text { by } \\
\text { selling the machinery } \\
\text { and proprietary rights }\end{array}$ & $\$ 400 \mathrm{M}$ & \\
\hline $\begin{array}{r}\text { Contract } \\
\text { option }\end{array}$ & $\begin{array}{l}\text { Contracting the product } \\
\text { variant by } 60 \% \text { will } \\
\text { retain only } 40 \% \text { of the } \\
\text { current value and a } \\
\text { total of } \$ 310 \mathrm{M} \text { in } \\
\text { salvage value and cost } \\
\text { savings }\end{array}$ & $\begin{array}{l}(0.4 * 750.58)+310= \\
\quad \$ 610.23 \mathrm{M}\end{array}$ & \\
\hline $\begin{array}{r}\text { Upgrade } \\
\text { option }\end{array}$ & $\begin{array}{l}\text { Upgrading the current } \\
\text { product variant with } \\
\text { new features to meet } \\
\text { the market demand } \\
\text { would increase the } \\
\text { revenue stream by } 10 \% \text {. } \\
\text { The upgrading cost is } \\
300 \mathrm{M}\end{array}$ & $\begin{array}{l}(1.1 * 750.58)-300= \\
\quad \$ 525.38 \mathrm{M}\end{array}$ & \\
\hline
\end{tabular}

value has reached after several downward movements in the market. A similar evaluation approach indicates that the company will be better off to abandon the product variant immediately at Node B. The various decisions made at other nodes at $t=5$ are shown in Table 8 .

\section{Evaluating Intermediate Nodes in the Binomial Decision Tree}

After evaluating the terminal nodes in the decision tree, we proceed to the intermediate nodes in the decision tree. The value of the unexercise option (or in other words, continue with the existing product variant as it is) is determined by using Equation (3). Figure 6 shows how the value of the unexercise option is calculated at Node D (refer to Table 6). The values of $V_{d^{3} u}, V_{d^{4}}$, and $V_{d^{3}}$ can be found from the asset value lattice created in Table 6 and $f_{d^{3} u}$ and $f_{d^{4}}$ can be calculated from the decisions made at the previous node using Equation 3 (refer to Table 8). For example, the value of the product variant at Node $\mathrm{D}, f_{d^{3}}$, is calculated as shown in Figure 6. 
Table 8. Decision tree and option valuation (in \$M)

\begin{tabular}{lccccc}
\hline$t=0$ & $t=1$ & $t=2$ & $t=3$ & $t=4$ & $t=5$ \\
\hline $508.088(U x)$ & $547.427(U x)$ & $590.89(U x)$ & $639.94(U x)$ & $693.06(U x)$ & $750.58(U x)$ \\
& $479.5(U x)$ & $506.11(U x)$ & $545.81(U x)$ & $591.11(U x)$ & $640.99(U x)$ \\
& & $472.03(C t)$ & $476.21(C t)$ & $503.99(U x)$ & $545.61(U x)$ \\
& & & $448.88(C t)$ & $460(A b)$ & $465.55(U x)$ \\
& & & & $460(A b)$ & $460(A b)$ \\
& & & & & $460(A b)$ \\
\hline
\end{tabular}

$U x$-Unexercise option should be exercised.

$C t$-Contract option should be exercised.

$A b$-Abandon option should be exercised.

$U p$-Upgrade option should be exercised.

The value of the decision at Node D is found as shown in Equation (8).

Decision Value $=\operatorname{Max}[438.09$ (for Unexercise option), $397.21 * 0.4$ +290 (for Contract option), $397.21 * 1.1$

- 400 (for Upgrade option), 400 (for Abandon option)]

Decision Value $=\$ 448.88 \mathrm{M}$, Contract the product variant

Clearly, contracting the product variant sales by $60 \%$ will help the company to be more profitable. Similarly, we find the decision values and the best strategic options to be considered at each decision node as shown in Table 8 . The numbers represent the decision values adjusted for flexibility. The best strategic decisions for each node are shown in parentheses in Table 8.

$$
\begin{aligned}
& V_{d^{3}}=397.21 f_{V_{d^{4}}=366.9}^{V_{d^{3} u}=430.03} f_{d^{3}}=?=460 \\
& f_{d^{3}}=\left(f_{d^{3} u} * p^{*}+f_{d^{4}} *\left(1-p^{*}\right)\right) /\left(1+R_{f}\right)^{\Delta t} \\
& =(460 * 0.7949+460 *(1-0.7949)) /(1+0.05)^{1} \\
& =438.09
\end{aligned}
$$

Figure 6. Options evaluation at Node D. 


\section{Decision 2: Selecting Future Concept Platform}

We evaluate each concept platform based on the real option methodology and implement a decision tree model. The following steps would show how to find the solution for Decision 2.

Step 1: Identify Options

As discussed earlier, the options we built for this case is a compound rainbow option, where the underlying asset is driven by multiple sources of uncertainties and the value of one option is contingent upon exercising the option of the upstream development phase.

\section{Step 2: Determining Uncertainties}

As discussed earlier, we consider three different types of uncertaintiestechnical, market and implementation uncertainties. The real options value for the product platform in consideration would depend on these factors.

- Technical Uncertainties: The evaluation analysis is subject to three different situations incorporating technical uncertainty of the NPD project. The risks associated with these events are determined by experienced project personnel.

1) R\&D produces an outstanding product platform, which in turn helps to produce outstanding product variants. The product variants derived from an outstanding platform will have a relatively higher market value. The probability of an outstanding $R \& D$ outcome is estimated to be $25 \%$.

2) R\&D produces a mediocre product platform that would in turn produce mediocre product variants with much relatively lesser market value. The probability of a mediocre $R \& D$ outcome is estimated to be $20 \%$.

3) $R \& D$ fails to produce any marketable product platform, which implies that there would not be any marketable product variants for the company. The probability of such a situation is estimated to be $55 \%$.

- Market Uncertainty: As per the case study, it is estimated that the market demand for the product variant could grow or decline by $20 \%$. If the $R \& D$ produces an outstanding product platform and the business grows at the same rate for two years, the derivative product variant can have a market value of $\$ 1296 \mathrm{M}$ at the end of second year. If the $R \& D$ produces an outstanding product platform and the business grows at $20 \%$ for the first year and declines by $20 \%$ in the next year then at the end of two years, the derivative product variant will have a market value of $\$ 664 \mathrm{M}$. Similarly, we can find the effects of market uncertainty on the value of the future product variants for different market situations and $R \& D$ outcome scenarios. 
- Implementation Uncertainty: This type of uncertainty considers manufacturing and other production-related uncertainties. As per the case study, the probability for proper implementation of an outstanding product platform is assumed to be one whereas the probability for proper implementation of a mediocre product platform is assumed to be $60 \%$.

The event/decision tree is shown in Figure 7. The decision tree depicts how different types of uncertainties can change the course of the platform development project. It also shows the static net present values of the different product variant outcomes. As mentioned earlier, the event tree shows the technological and market uncertainties next to each other.

For evaluation purposes, we simplify the event/decision tree by showing the asset value lattice and the corresponding option value at each node (refer to Figure 8 and Table 10). The asset/option value lattice in Figure 8 shows how the value of the underlying platform can vary over time.

\section{Step 3: Strategic Option Valuation and Decision Rule}

The evaluation starts at the terminal nodes (refer to Figure 7 and Table 10). In Table 10, we denote the options values at the terminal nodes as $C_{S U, O U}$, $C_{S U, O D}, C_{S U, M U}, C_{S D, O U}$, etc. For example, $C_{S U, O U}$ indicates call option value when the first year $R \& D$ is successful (denoted by $S$ ), and the market demand is upward (denoted by $U$ ), and the second year R\&D produces outstanding product platform (denoted by $O$ ), and market demand is upward (denoted by $\mathrm{U}$ ). Refer to appendix 1 for the nomenclature used in this article. Once the decisions are made at the terminal nodes, the evaluation procedure moves backward in the asset/option value lattice to find the platform option values at the intermediate decision nodes. Finally, we find the net option value (NOV) at the initial node.

\section{Evaluation at the Terminating Nodes}

The evaluation starts at the terminal nodes (refer to Figure 7 and Table 10). The options values based on the R\&D outcome and market conditions are shown in Figure 7 and Table 10. The investment decision is made only when the payoff adjusted for implementation uncertainty at the terminal nodes is larger than the cost of investment at the respective decision node. We show the calculation of the decision values for all the terminating nodes in appendix 2.

\section{Evaluating Platform Decisions at Intermediate Nodes}

Now moving backwards in the asset/option value lattice (refer to Figure 7 and Table 10), we evaluate options at the intermediate nodes using the risk neutral methodology. The probability calculations are shown in Table 9. The calculations for options valuation and decisions made at different nodes are shown in Figure 7 and Table 10. The evaluation procedures at all the intermediate nodes are shown in appendix 2. 


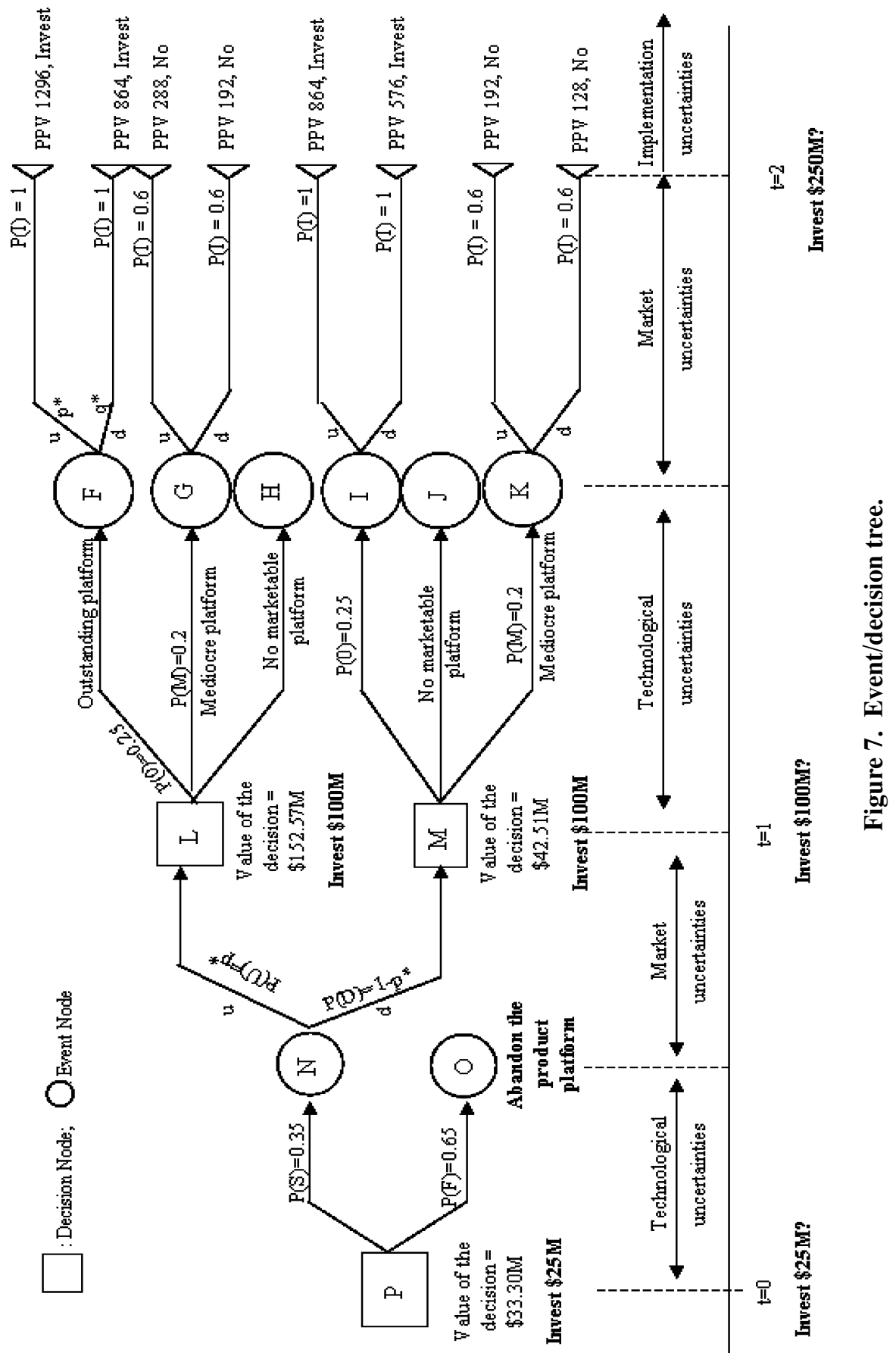



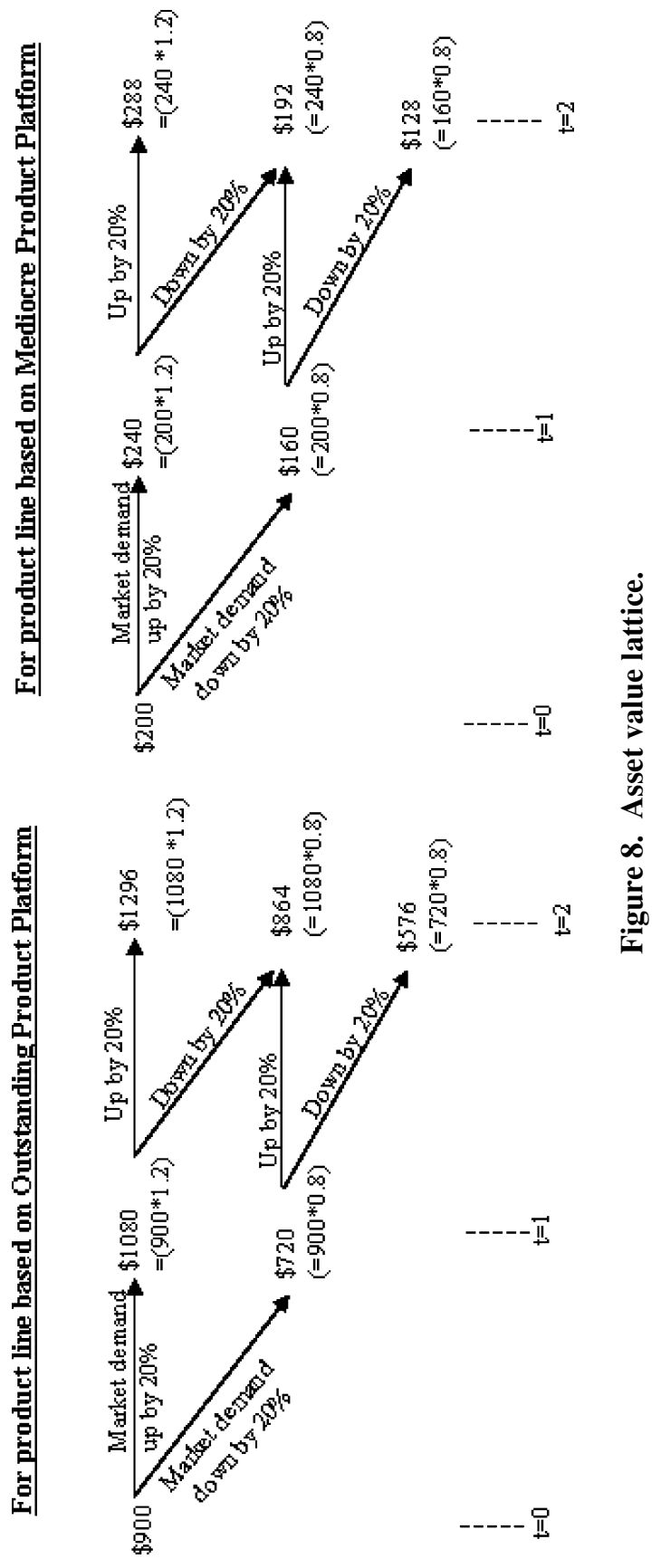
Table 9. Probability calculations for decision 2

\begin{tabular}{|c|c|c|}
\hline Time period & Binomial probability & Multinomial probability \\
\hline \multirow{3}{*}{ Between $\mathrm{t}=0$ and $\mathrm{t}=1$} & $\begin{array}{l}\mathrm{P}(\mathrm{S})=0.55 \\
\mathrm{P}(\mathrm{F})=0.45\end{array}$ & $\begin{array}{c}\mathrm{P}(\mathrm{SU})=\mathrm{P}(\mathrm{S}) *(\mathrm{PU})=0.34 \\
\mathrm{P}(\mathrm{SD})=\mathrm{P}(\mathrm{S}) * \mathrm{P}(\mathrm{D})=0.21\end{array}$ \\
\hline & $\mathrm{P}(\mathrm{U})=\mathrm{p}^{*}=0.63$ & $\begin{array}{l}\mathrm{P}(\mathrm{FU})=\mathrm{P}(\mathrm{F}) * \mathrm{P}(\mathrm{U})=0.28 \\
\mathrm{P}(\mathrm{FD})=\mathrm{P}(\mathrm{F}) * \mathrm{P}(\mathrm{D})=0.17\end{array}$ \\
\hline & $P(D)=1-p^{*}=0.38$ & Sum $=1.00$ \\
\hline \multirow[b]{2}{*}{ Between $\mathrm{t}=1$ and $\mathrm{t}=2$} & $\begin{array}{l}\mathrm{P}(\mathrm{O})=0.3 \\
\mathrm{P}(\mathrm{M})=0.25 \\
\mathrm{P}(\mathrm{N})=0.45\end{array}$ & $\begin{array}{l}\mathrm{P}(\mathrm{OU})=\mathrm{P}(\mathrm{O})^{*} \mathrm{P}(\mathrm{U})=0.19 \\
\mathrm{P}(\mathrm{OD})=\mathrm{P}(\mathrm{O})^{*} \mathrm{P}(\mathrm{D})=0.11 \\
\mathrm{P}(\mathrm{MU})=\mathrm{P}(\mathrm{M})^{*} \mathrm{P}(\mathrm{U})=0.16\end{array}$ \\
\hline & $\begin{array}{c}\mathrm{P}(\mathrm{U})=P^{*}=63 \\
\mathrm{P}(\mathrm{D})=1-\mathrm{p}^{*}=0.38\end{array}$ & $\begin{array}{c}\mathrm{P}(\mathrm{MD})=\mathrm{P}(\mathrm{M}) * \mathrm{P}(\mathrm{D})=0.09 \\
\mathrm{P}(\mathrm{NU})=\mathrm{P}(\mathrm{N}) * \mathrm{P}(\mathrm{U})=0.28 \\
\mathrm{P}(\mathrm{ND})=\mathrm{P}(\mathrm{N}) * \mathrm{P}(\mathrm{D})=0.17 \\
\mathrm{Sum}=1.00\end{array}$ \\
\hline
\end{tabular}

Finally, moving backward to $t=0$, we find

$\mathrm{C}(0)=$ Platform Option Value $=\$ 58.30 \mathrm{M}$

$\mathrm{NOV}=$ Value of the decision made at Node $\mathrm{P}=\operatorname{Max}(0,58.30,-25)$

$$
=\$ 33.30 \mathrm{M}>0
$$

Table 10. Options valuation

\begin{tabular}{|c|c|c|c|}
\hline \multirow[b]{2}{*}{$\begin{array}{l}\text { Invest \$25M? } \\
t=0\end{array}$} & \multicolumn{3}{|c|}{ Options valuation and decision making } \\
\hline & $\begin{array}{c}\text { Invest } \$ 100 \mathrm{M} ? \\
t=1\end{array}$ & \multicolumn{2}{|c|}{$\begin{array}{c}\text { Invest } \$ 250 \mathrm{M} ? \\
\quad t=2\end{array}$} \\
\hline & $\begin{array}{l}\text { Option Value, } \mathrm{C}_{\mathrm{SU}} \\
\quad=252.57\end{array}$ & $\mathrm{C}_{\mathrm{SU}, \mathrm{OU}}=1046.00$ & Decision: Yes, Invest \\
\hline & $\begin{array}{l}\text { Decision Value } \\
\quad=15257\end{array}$ & $\mathrm{C}_{\mathrm{SU}, \mathrm{OD}}=614.00$ & Decision: Yes, Invest \\
\hline & Decision: Yes. invest & $\mathrm{C}_{\mathrm{SU}, \mathrm{MU}}=\mathbf{0 . 0 0}$ & Decision: Yes, Invest \\
\hline & & $\mathrm{C}_{\mathrm{SU}, \mathrm{MD}}=\mathbf{0 . 0 0}$ & Decision: No, Do not Invest \\
\hline & & $\mathrm{C}_{\mathrm{SU}, \mathrm{NP}}=\mathbf{0 . 0 0}$ & Decision: No, Do not Invest \\
\hline$C(0)=58.30$ & $\begin{array}{l}\text { Option Value, } C_{\mathrm{SD}} \\
\quad=142.51\end{array}$ & $\mathrm{C}_{\mathrm{SD}, \mathrm{OU}}=614.00$ & Decision: Yes, Invest \\
\hline $\begin{array}{l}\text { Decision Value } \\
\quad=33.30\end{array}$ & $\begin{array}{l}\text { Decision Value } \\
\quad=42.51\end{array}$ & $\mathrm{C}_{\mathrm{SD}, \mathrm{OD}}=326.00$ & Decision: Yes, Invest \\
\hline \multirow[t]{6}{*}{ Decision: Yes Invest } & Decision: Yes. invest & $\mathrm{C}_{\mathrm{SD}, \mathrm{MU}}=\mathbf{0 . 0 0}$ & Decision: No. Do not Invest \\
\hline & & $\mathrm{C}_{\mathrm{SU}, \mathrm{MD}}=0.00$ & Decision: No. Do not Invest \\
\hline & & $\mathrm{C}_{\mathrm{SU}, \mathrm{NP}}=\mathbf{0 . 0 0}$ & Decision: No. Do not Invest \\
\hline & $\begin{array}{l}\text { Option Value, } \mathrm{C}_{\mathrm{NP}} \\
=0.00\end{array}$ & & \\
\hline & $\begin{array}{l}\text { Decision Value } \\
\quad=0.00\end{array}$ & & \\
\hline & Decision: Abandon & & \\
\hline
\end{tabular}


Table 11. Real option value for all the concept platforms

\begin{tabular}{lc}
\hline Concept platforms & $\begin{array}{c}\text { Net option value (NOV) } \\
\text { (in million dollar) }\end{array}$ \\
\hline Concept platform \#1 & 33.30 \\
Concept platform \#2 & 0.23 \\
Concept platform \#3 & 2.91 \\
\hline
\end{tabular}

Since the NOV $>0$, the decision-maker should invest $\$ 25 \mathrm{M}$ in this platform project.

\section{Selecting the Best Concept Platform}

To select the best platform concept, one needs to find the NOV of each concept platform using the procedure described in the above sections. For example purposes, we assume that the NOV of the three concept platforms considered are as given in Table 11.

From Table 11, it is clear that

$$
\begin{aligned}
\text { NOV }(\text { Concept Platform \# 1) } & >\operatorname{NOV}(\text { Concept Platform \# 3) } \\
& >\operatorname{NOV}(\text { Concept Platform \# 2) }
\end{aligned}
$$

Therefore, the company should proceed with the concept platform \#1 and invest money in this project.

\section{DISCUSSION}

In the illustrative case presented in this article, the product variants were offered sequentially one after the other. The total static market value of the product variants was determined by adding the individual static market values. However, if the company planned to offer the product variants (using the same platform) concurrently to serve different market segments as shown in the HP's case (800 Platform) in Figure 1, the practitioner could still follow a similar evaluation methodology. In both cases, the net static market value is found at $t=0$ when R\&D starts (refer to Figure 9), and this net static value is used to understand the effects of market uncertainties on product variant value. Once the effects of market uncertainties are determined it would be possible to find the NOV and to select the best platform. It is important to mention that the current methodology assumes that there is no cannibalization among the product variants. In other words, the market value of each product variant is independent of the market value of another 

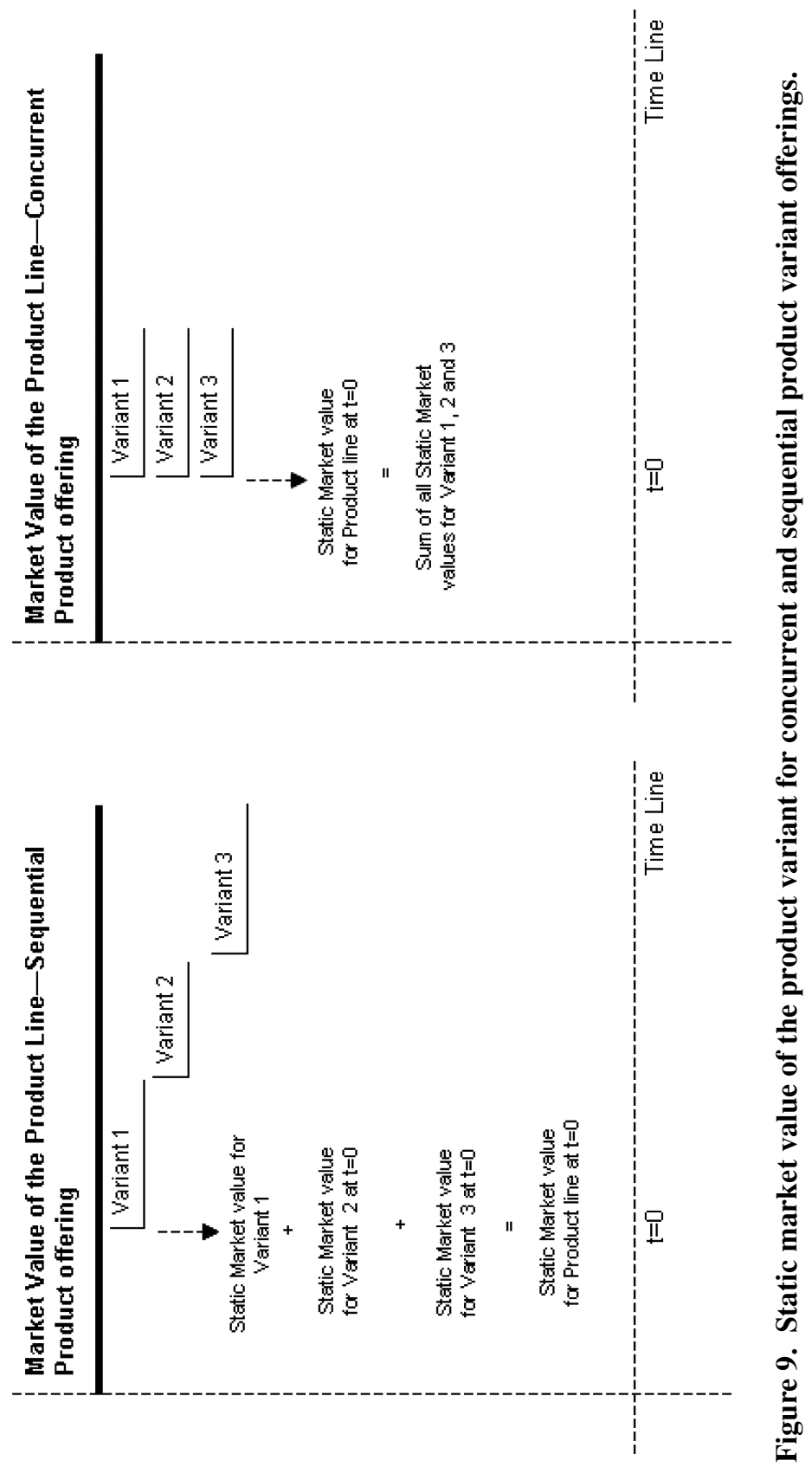
product variant derived from the same platform. This assumption allows us to find the net market value by simply adding the individual market values.

Product planning begins well before the commencement of actual product/platform development. During the planning stage, managers often juggle with many options or choices of strategies. Their main concern is which product options will create the best possible payoff for the company. The proposed decision tree with real options methodology is a promising decision-planning tool where the values of the underlying asset are adjusted for possible uncertain events. Once the decision tree is prepared, the planning for the underlying asset's future becomes much easier. There are some initial obstacles to the actual implementation of our methodology. These concerns are similar to the ones voiced by Lint and Pennings (2003). Specifically, the estimation of uncertainties, prediction of future revenues, and listing of various options available at any given point in time will require that the management use its best available judgment. For instance, Lint and Pennings (2003) found that sales predictions and business events at Philips Electronics could be used as pointers to estimate uncertainties. In a case study at Merck, Nicholas (1994) used the average stock volatility of companies in the same business as a surrogate for computing project uncertainty.

Evaluating the platform development projects without considering competition is still limiting. We realize that the proposed real option model is static in nature as the model stands on assumption that the information is complete (Taniyama, 2002), and the proposed methodology does not consider the possible future strategic moves of the competitors. For example, after HP introduced an all renewed cheaper printer product variants, HP's competitors responded. Lexmark also introduced a completely renewed inkjet line to capture a piece of the 50\% HP market share (Coleman, 2003). Analysts had predicted that HP would face fierce competition from Lexmark. Now the question is what would the best strategy be for HP to keep its position intact? After all, HP spent almost one billion dollars in revamping the product variant. Quite often, such strategies bring price wars. HP and Lexmark, Proctor \& Gamble (P\&G), and Kimberly-Clarke are some example corporations where competition is intense (Fang et al., 2002). One future direction of research could involve investigating the possibility of using a game theoretic approach at different nodes of the decision tree by introducing games that represent competitive strategic moves.

\section{CONCLUSIONS}

Huge investments are required to execute product plans. In many cases, the outcomes are riddled with payoff uncertainties. This article presents a 
real options model to evaluate multistage product planning projects. In our methodology, the uncertainties involved in the platform development and planning process have been integrated into the evaluation process for better decision-making. We considered two critical product planning decisions; namely, platform decisions and product variant decisions. The platform decision is actually a superset of the product variant decision. The current work can be extended by including the consideration of concurrent selection of multiple product platforms at a given point in time while including the effect of cannibalization of competing product variants from both within a company and its competitors.

\section{REFERENCES}

Amram, M. and Kulatilaka, N. (1999) Real options-Managing strategic investment in an uncertain world. Boston: HBS Press.

Antonsson, E.K. and Cagan, J. (2001) Formal engineering design synthesis. Cambridge, UK: Cambridge University Press.

Black, F. and Scholes, M. (1973) The pricing of options and corporate liabilities.Journal of Political Economy, 81, 637-659.

Brandao, L.E. and Dyer, J.S. (2003) Decision analysis and real options: A discrete time approach to real option valuation. Unpublished manuscript, University of Texas, Austin.

Brealey, R.A. and Myers, S. (2000) Principles of corporate finance. IL: Irwin McGrawHill, Publishers, Boston, MA.

Cagan, J. and Vogel, C.M. (2002) Creating breakthrough products: Innovation from product planning to program approval. Upper Saddle River, NJ: Prentice Hall.

Coleman, M. (2003, April 28) Lexmark to start selling first sub-\$100 multifunction printer. Investor's Business Daily.

Copeland, T. and Antikarov, V. (2001) Real options—A practitioner's guide. New York: Texere LLC.

Copeland, T. and Weiner, J. (1990) Proactive management of uncertainty. The McKinsey Quarterly, 4, 133-152.

Cox, J., Ross, S., and Rubenstein, M. (1979) Option pricing: A simplified approach. Journal of Financial Economics, 7, 229-264.

de Neufville, R. (2001) Real options: Dealing with uncertainty in systems planning and design. Integrated Assessment Journal, 4(1), 26-34.

Dixit, A. (1989) Entry and exit decisions under uncertainty. Journal of Political Economy, 97, 620-638.

Dixit, A.K. and Pindyck, R.S. (1994) Investment under uncertainty. Princeton, NJ: Princeton University Press.

Dixit, A. and Pindyck, R.S. (1995) The options approach to capital investment. Harvard Business Review, (May-June 1995) 105-118.

Fang, B., Feng, Y.H., Yuan, T.L., and Dejun, X. (2002) The duopoly in the diaper industry. Available at: http://www.olin.wustl.edu/faculty/macdonald/ (accessed April 10, 2003). 
Geppert, B. and Roessler, F. (2001) Combining product line engineering with options thinking. Avaya Labs Research Technical Report (ALR-2001-011), Proceeding of In proceedings of PLEES 01-Product Line Engineering-The Early Steps, Erfurt, Germany, September 13, 2001.

Grupp, H. and Maital, S. (2001) Managing new product development and innovation: A Microeconomic Tool box. Cheltenham, UK; Northampton USA, Edward Elgar Publishing.

Halman, J.I.M., Hofer, A.P., and van Vuuren, W. (2006) Platform-driven development of product families: Linking theory with practice. In Product platform and product family design: Methods and applications, eds. T.W. Simpson, Z. Siddique, and J. Jiao. Springer, New York.

Herath, H.S.B. and Park, C.S. (1999) Economic analysis of R\&D projects: An options approach. The Engineering Economist, 44(1), 1-35.

Huchzermeier, A. and Loch, C.H. (2001) Project management under risk: Using the real options approach to evaluate flexibility in R\&D. Management Science, 47(1), 85-101.

Hull, J. (2006) Options, futures and other derivatives. Upper Saddle River, NJ: PrenticeHall.

Jiao, J., Kumar, A., and Lim, C.M. (2006) Real options identification and valuation for the financial analysis of product family design. Proceedings of the IMechE Part B: Journal of Engineering Manufacture. 220(6), 929-939.

Kellog, D. and Charnes, J.M. (2000) Real-options valuation for a biotechnology company. Financial Analysts Journal, 56(3), 76-84.

Krishnan, V. and Gupta, S. (2001) Appropriations and impact of platform based product development.Management Science, 47(1), 52-68.

Leslie, K.J. and Michaels, M.P. (1997) The real power of real options. The Mckinsey Quarterly. 3, 4-22.

Lim, C.M., Jiao, J., Kumar, A., and Zhang, Y. (2005) Identification of real options for product family configuration design. Paper presented at the International Conference on Product Lifecycle Management: Emerging Solutions and Challenges for Global Networked Enterprise, Lyon, France, 11-13th July 2005.

Lint, O. and Pennings, E. (2003) An options approach to new product development: Experience from Phillips Electronics. In Real R\&D options (D. Paxson, ed.), Oxford. Butterworth-Heinemann, 48-66.

Merton, R.C. (1973) Theory of rational option pricing. Bell Journal of Economics and Management Science, 4(1), 141-183.

Meyer, M.H. and Lehnerd, A.P. (1997) The power of product platforms. New York: Free Press.

Mun, J. (2002) Real options analysis. Hoboken, NJ: John Wiley \& Sons.

Myers, S. (1977) Determinants of capital borrowing. Journal of Financial Economics, 5, 147-175.

Nicholas, N.A. (1994) Scientific management at Merck: An interview with CFO Judy Lewent.Harvard Business Review Jan 1, 1994, 88-91.

Otto, K. and Hölttä-Otto, K. (2005) Platform concept selection. In Product platform and product family design: Methods and applications, eds. T.W. Simpson, Z. Siddique, and J. Jiao. New York: Springer. 
Otto, K.N. and Wood, K.L. (2001) Product design: Techniques in reverse engineering and new product development. Upper Saddle River, NJ: Prentice Hall.

Pahl, G. and Beitz, W. (1996) Engineering design: A systematic approach, 2 d ed. Translated by K. Wallace, L. Blessing, and F. Bauert. London: Springer-Verlag.

Park, C.S. and Herath, H.S.B. (2000) Exploring uncertainty-investment opportunities as real options: A new way of thinking in engineering economics. The Engineering Economist, 45(1), 1-32.

Pavlic, D., Pavkovic, N., and Storga, M. (2002) Variant design based on product platform. Paper presented at the International Design Conference-Design 2002, 14-17 May, Dubrovnik.

Pine, B.J., II (1993) Mass customization: The new frontier in business competition. Boston: Harvard Business School Press.

Pugh, S. (1996) Creating innovative products: Using total design. Reading, MA: AddisonWesley.

Ramirez, N. (2002) Valuing flexibility in infrastructure developments: The Bogotá water supply extension plan. MS thesis, MIT, Cambridge, MA.

Sanderson, S. and Uzumeri, M. (1995) Managing product families: The case of Sony Walkman. Research Policy. 24(5), 761-782.

Shetty, D. (2002) Design for product success. Dearborn, MI: Society for Manufacturing Engineers.

Simpson, T.W., Siddique, Z., and Jiao, J., Eds. (2005) Product platform and product family design: Methods and applications. New York: Springer.

Smith, J.E. and Nau, R.F. (1995) Valuing risky projects: Option pricing theory and decision analysis. Management Science, 41(5), 795-816.

Suh, E.S. (2005) Flexible product platforms. Ph.D. dissertation, MIT, Cambridge, MA.

Taniyama, T. (2002) The strategic market entry in an age of discontinuity: A real options approach. Bachelor's thesis, Keio University, Japan.

Tichem, M., Andreasen, M., and Riitahuhta, A. (1999) Design of product families. In International Conference on Engineering Design, ICED 99, August 24-26, 1999, Munich, Germany.

Titman, S. (1985) Urban land prices under uncertainty. American Economic Review, $75(3), 505-514$.

Trigeorgis, L. (1988) A conceptual options framework for capital budgeting. Advances in Futures and Options Research, 3, 145-167.

Trigeorgis, L. (1991) A log-transformed binomial numerical analysis method for valuing complex multi-option investment. Journal of Financial and Quantitative Analysis, 26(3), 309-326.

Trigeorgis, L. (1996) Real options: Managerial flexibility and strategy in resource allocation. Managerial and Decision Economics, 18(3), 66-68, Cambridge, MA: MIT Press.

Ulrich, K. (1995) The role of product architecture in the manufacturing firm. Research Policy, 24(3), 419-440.

Ulrich, K.T. and Eppinger, S.D. (2000) Product design and development. London: Irwin McGraw Hill. 
Uzumeri, M. and Sanderson, S. (1995) A framework for model and product family competition. Research Policy, 24(4), 583-607.

van Vuuren, W. and Halman, J.I.M. (2001) Platform driven development of product families: Linking theory with practice. Paper presented at "The Future of Innovation Studies" conference, 20-23 September, Eindhoven University of Technology, The Netherlands.

Watson, N. (2003, February 17) What's wrong with this printer? Fortune. 147(3). Williams, J.T. (1991). Real Estate Development as an Option, The Journal of Real Estate Finance and Economics, Springer. 4(2), 191-208.

\section{APPENDIX 1}

\section{Nomenclature}

$u: \quad$ Up-state factor

$d: \quad$ Down-state factor

$\sigma: \quad$ Implied volatility in the future cash flow

$\Delta t: \quad$ Stepping time in the decision lattice

$V_{0}: \quad$ Static net present value (for Decision 1)

$V_{1 u}$ : Up-state asset value (for Decision 1)

$V_{1 d}: \quad$ Down-state asset value (for Decision 1)

$f: \quad$ Value of the unexercise option at the intermediate nodes (for Decision 1)

$f_{t u}: \quad$ Value of the decision made in the up state (for Decision 1)

$f_{t d}$ : $\quad$ Value of the decision made in the down state (for Decision 1)

$p *: \quad$ Risk-neutral probability

$R_{f}: \quad$ Risk-free rate

$U_{x}$ : $\quad$ Unexercise option (for Decision 1)

$C_{t}$ : $\quad$ Contract option (for Decision 1)

$A_{b}: \quad$ Abandon option (for Decision 1)

$U_{p}$ : $\quad$ Upgrade option (for Decision 1)

$P(S): \quad$ Probability of successful R\&D result during phase one (between $t=0$ and $t=1$ )

$P(F)$ : Probability of failed R\&D during phase one (between $t=0$ and $t=1)$

$P(U): \quad$ Probability of up-state market

$P(D)$ : $\quad$ Probability of down-state market

$P(O)$ : $\quad$ Probability of outstanding product platform (between $t=1$ and $t=2)$

$P(M)$ : $\quad$ Probability of mediocre product platform (between $t=1$ and $t=2$ )

$P(N P)$ : Probability of no marketable product platform (between $t=1$ and $t=2$ ) 
$P(I): \quad$ Probability of implementation (for Decision 2)

$P(S U)$ : Probability of successful R\&D and upward market (between $t=0$ and $t=1$ )

$P(S D)$ : Probability of successful R\&D and downward market (between $t=0$ and $t=1$ )

$P(F U): \quad$ Probability of failed R\&D and upward market

$P(F D)$ : Probability of R\&D failure and downward market

$P(O U)$ : Probability of outstanding platform development and upward market (between $t=1$ and $t=2$ )

$P(O D)$ : Probability of outstanding platform development and downward market (between $t=1$ and $t=2$ )

$P(M U)$ : Probability of mediocre platform development and upward market (between $t=1$ and $t=2$ )

$P(M D)$ : Probability of mediocre platform development and downward market (between $t=1$ and $t=2$ )

$P(N U)$ : Probability of no marketable platform and upward market (between $t=1$ and $t=2$ )

$P(N D)$ : Probability of no marketable platform and downward market (between $t=1$ and $t=2$ )

$C: \quad$ Real options values at different intermediate nodes (for Decision 2)

$C_{t i}: \quad$ Value of the decisions made at the end of the time period (for Decision 2)

$p_{i}^{\prime}$ : $\quad$ Multinomial probability respective to $C_{t i}$ (for Decision 2)

PPV: $\quad$ Product platform value (for Decision 2)

$C_{S U, O U}$ : Call options value when the first year R\&D is successful, and the market demand is upward, and the second year R\&D produces outstanding product platform, and market demand is upward (at $t=2$ )

$C_{S U, O D}$ : Call options value when the first year R\&D is successful, and the market demand is upward, and the second year R\&D produces outstanding product platform, and market demand is downward (at $t=2$ )

$C_{S U, M U}$ : Call options value when the first year $\mathrm{R} \& \mathrm{D}$ is successful, and the market demand is upward, and the second year R\&D produces mediocre product platform, and market demand is upward (at $t=2$ )

$C_{S U, M D}$ : Call options value when the first year R\&D is successful, and the market demand is upward, and the second year R\&D produces mediocre product platform, and market demand is downward (at $t=2$ ) 
$C_{S U, N P}$ : Call options value when the first year $\mathrm{R} \& \mathrm{D}$ is successful, and the market demand is upward, and the second year $\mathrm{R} \& \mathrm{D}$ produces no marketable platform (at $t=2$ )

$C_{S D, O U}:$ Call options value when the first year $\mathrm{R} \& \mathrm{D}$ is successful, and the market demand is downward, and the second year R\&D produces outstanding product platform, and market demand is upward (at $t=2$ )

$C_{S D, O D}$ : Call options value when the first year R\&D is successful, and the market demand is downward, and the second year $R \& D$ produces outstanding product platform, and market demand is downward (at $t=2$ )

$C_{S D, M U}$ : Call options value when the first year $\mathrm{R} \& \mathrm{D}$ is successful, and the market demand is downward, and the second year R\&D produces mediocre product platform, and market demand is upward (at $t=2$ )

$C_{S D, M D}$ : Call options value when the first year $\mathrm{R} \& \mathrm{D}$ is successful, and the market demand is downward, and the second year R\&D produces mediocre product platform, and market demand is downward (at $t=2)$

$C_{S U}$ : Call options value when the first year R\&D is successful, and the market demand is upward (at $t=1$ )

$C_{S D}: \quad$ Call options value when the first year $\mathrm{R} \& \mathrm{D}$ is successful, and the market demand is downward (at $t=1$ )

$C_{N P}: \quad$ Call options value when no marketable platform is developed

\section{APPENDIX 2}

Calculations for Options Evaluation (for Decision 2) 


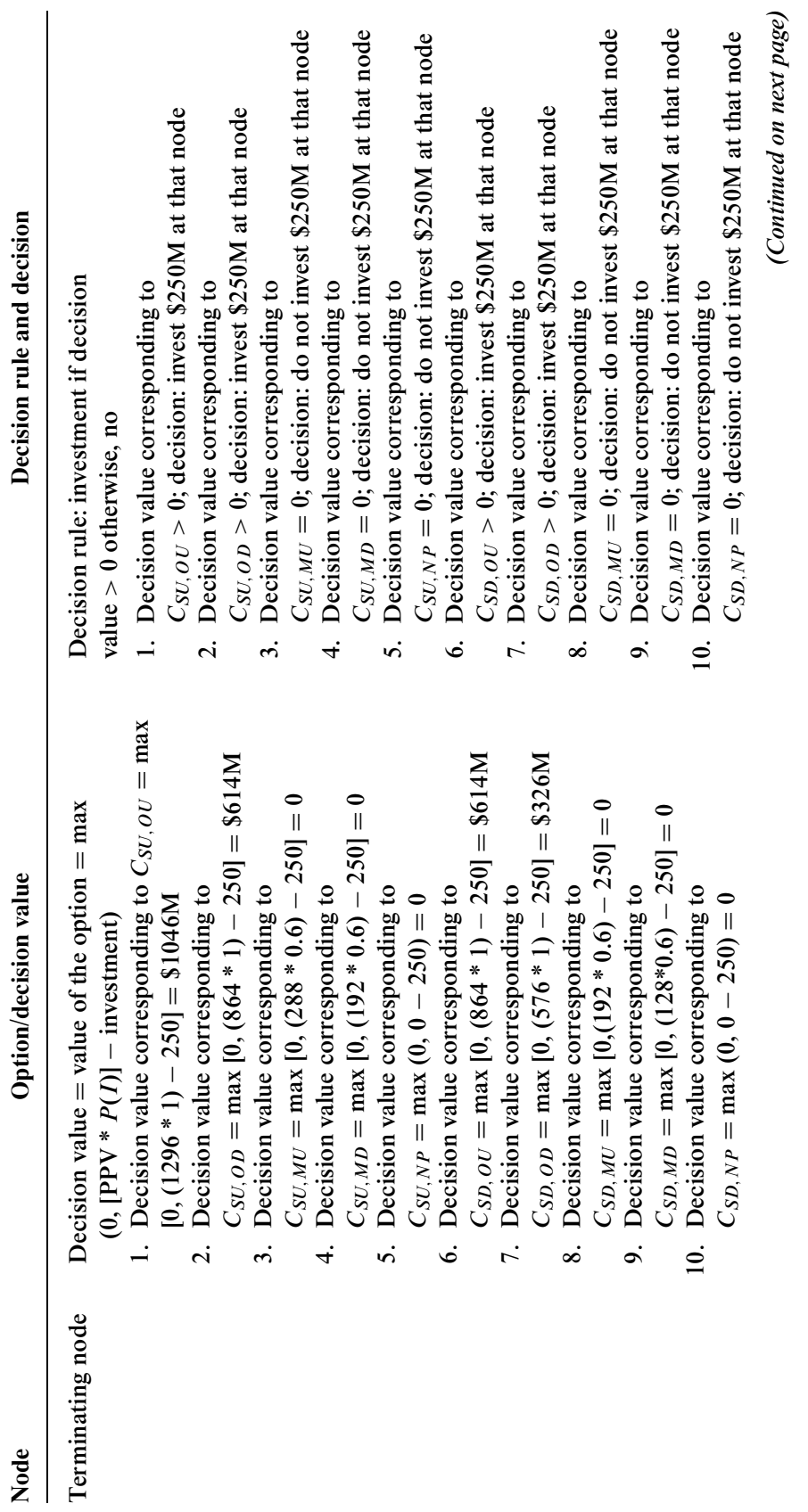




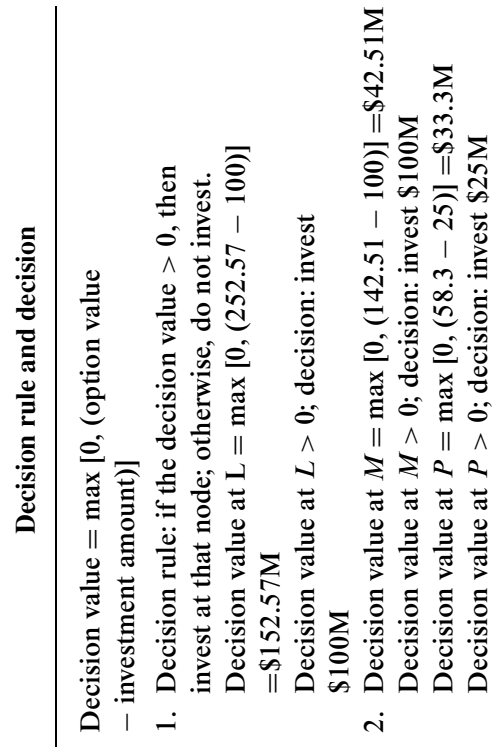

2SS

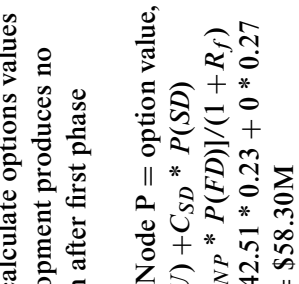

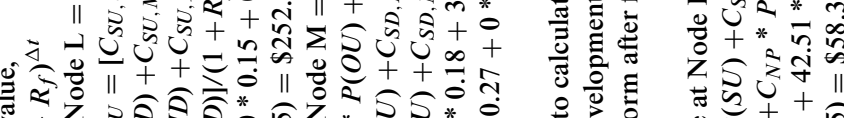

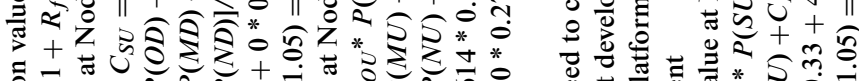

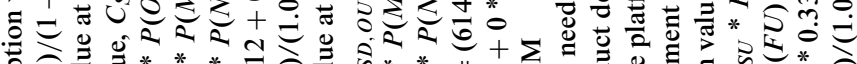

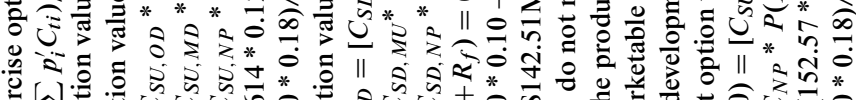

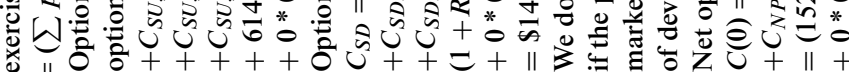

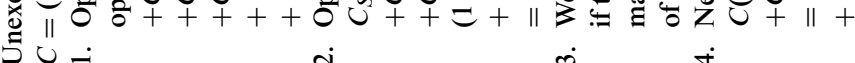




\section{BIOGRAPHICAL SKETCHES}

Prasenjit Shil is a Ph.D. student in the Engineering Management \& Systems Engineering Department at the University of Missouri-Rolla (UMR). Prasenjit's research interests include product development and management and financial modeling. He has received the Future Leaders of Manufacturing award from the Society of Manufacturing Engineers (SME) in 2004, the Outstanding Graduate Student Leadership award from Engineering Management and Systems Engineering Department, UMR, in 2006, and an Honorable Mention in the Engineering Management Department Research Poster Competition in 2007. He has been president of several student organizations at UMR.

Venkat Allada is a professor in the Engineering Management \& Systems Engineering Department at the University of Missouri-Rolla (UMR). His teaching and research interests include intelligent design and manufacturing, product platforms, sustainable product engineering, and lean enterprise systems. He is the recipient of the Outstanding Young Manufacturing Engineer award from the Society of Manufacturing Engineers (SME) and the Outstanding New Faculty award from the American Society of Engineering Education (ASEE). 
Copyright of Engineering Economist is the property of Taylor \& Francis Ltd and its content may not be copied or emailed to multiple sites or posted to a listserv without the copyright holder's express written permission. However, users may print, download, or email articles for individual use. 